\title{
Fourier Transform Infrared and Ultraviolet-Visible Spectroscopic Characterization of Ammonium Acetate and Ammonium Chloride: An Impact of Biofield Treatment
}

\author{
Mahendra Kumar Trivedi ${ }^{1}$, Alice Branton ${ }^{1}$, Dahryn Trivedi ${ }^{1}$, Gopal Nayak ${ }^{1}$, Khemraj Bairwa ${ }^{2}$ and Snehasis Jana ${ }^{\star}$ \\ ${ }^{1}$ Trivedi Global Inc., 10624 S Eastern Avenue Suite A-969, Henderson, NV 89052, USA \\ ${ }^{2}$ Trivedi Science Research Laboratory Pvt. Ltd., Hall-A, Chinar Mega Mall, Chinar Fortune City, Hoshangabad Rd., Bhopal, Madhya Pradesh, India
}

\begin{abstract}
Ammonium acetate and ammonium chloride are the white crystalline solid inorganic compounds having wide application in synthesis and analytical chemistry. The aim of present study was to evaluate the impact of biofield treatment on spectral properties of inorganic salt like ammonium acetate and ammonium chloride. The study was performed in two groups of each compound i.e., control and treatment. Treatment groups were received Mr. Trivedi's biofield treatment. Subsequently, control and treated groups were evaluated using Fourier Transform Infrared (FT-IR) and Ultraviolet-Visible (UV-Vis) spectroscopy. FT-IR spectrum of treated ammonium acetate showed the shifting in wavenumber of vibrational peaks with respect to control. Like, the $\mathrm{N}-\mathrm{H}$ stretching was shifted from $3024-3586 \mathrm{~cm}^{-1}$ to $3033-3606 \mathrm{~cm}^{-1}$, C-H stretching from 2826-2893 $\mathrm{cm}^{-1}$ to $2817-2881 \mathrm{~cm}^{-1}, \mathrm{C}=\mathrm{O}$ asymmetrical stretching from $1660-1702$ $\mathrm{cm}^{-1}$ to $1680-1714 \mathrm{~cm}^{-1}$, N-H bending from $1533-1563 \mathrm{~cm}^{-1}$ to $1506-1556 \mathrm{~cm}^{-1}$ etc. Treated ammonium chloride showed the shifting in IR frequency of three distinct oscillation modes in $\mathrm{NH}_{4}$ ion i.e., at $v_{1}, 3010 \mathrm{~cm}^{-1}$ to $3029 \mathrm{~cm}^{-1} ; v_{2}, 1724 \mathrm{~cm}^{-1}$ to $1741 \mathrm{~cm}^{-1}$; and $v_{3}, 3156 \mathrm{~cm}^{-1}$ to $3124 \mathrm{~cm}^{-1}$. The $\mathrm{N}-\mathrm{Cl}$ stretching was also shifted to downstream region i.e., from 710 $\mathrm{cm}^{-1}$ to $665 \mathrm{~cm}^{-1}$ in treated ammonium chloride. UV spectrum of treated ammonium acetate showed the absorbance maxima $\left(\lambda_{\text {max }}\right)$ at $258.0 \mathrm{~nm}$ that was shifted to $221.4 \mathrm{~nm}$ in treated sample. UV spectrum of control ammonium chloride exhibited two absorbance maxima $\left(\lambda_{\max }\right)$ i.e., at 234.6 and $292.6 \mathrm{~nm}$, which were shifted to 224.1 and $302.8 \mathrm{~nm}$, respectively in treated sample.
\end{abstract}

Overall, FT-IR and UV data of both compounds suggest an impact of biofield treatment on atomic level i.e., at force constant, bond strength, dipole moments and electron transition energy between two orbitals of treated compounds as compared to respective control.

Keywords: Ammonium acetate; Ammonium chloride; Biofield treatment; Fourier transform infrared spectroscopy; Ultraviolet spectroscopy

\section{Introduction}

Ammonium acetate $\left(\mathrm{CH}_{3} \mathrm{COONH}_{4}\right)$ is a white crystalline solid, water soluble compound derived from the chemical reaction ammonia and acetic acid. Being a salt of weak base and weak acid, it possesses several distinct applications like, it is used as an aqueous buffer for High-Performance Liquid Chromatography (HPLC) with Evaporative Light Scattering Detector (ELSD) and Electrospray Ionization Mass Spectrometry (ESI-MS) of proteins [1,2]. It is also used as a food additive to regulate the acidity. Therapeutically, it is reported as an antidiuretic and antipyretic and also as a nutrient [1,3]. Ammonium acetate is also used as an intermediate and catalyst in numerous chemical reactions $[1,4]$. On the contrary, ammonium acetate also associated with its toxicities like flaccidity of facial muscles, generalized discomfort, tremor, anxiety, and impairment of motor performance [3].

Ammonium chloride $\left(\mathrm{NH}_{4} \mathrm{Cl}\right)$ is also a white crystalline inorganic salt, having high solubility in water. The natural and mineralogical form of ammonium chloride is known as sal ammoniac. The ammonium chloride has wide application in the field of medicine, agriculture and in food. In medicine, it is used as an expectorant in cough syrup due to irritative effect on the bronchial mucosa. Ammonium chloride causes the nausea and vomiting effects owing to irritative effect on gastric mucosa [5]. It is also used as a systemic acidifying agent for the treatment of severe metabolic alkalosis, and to maintain the urine at acidic $\mathrm{pH}$ in the treatment of urinary-tract disorders [6]. In food products, ammonium chloride is used as an additive or feed supplement for cattle and as a nutrient for yeast and other microbes $[7,8]$. It is also used to improve the crispness of cookies and snacks items. In agriculture, the ammonium chloride is used as an important source of nitrogen in fertilizers [9]. The chemical and physical stability of any chemical compound are most desired qualities that determine its shelf life and effectiveness [10]. Hence, it is advantageous to find out an alternate approach, which could enhance the stability of compounds by altering the structural properties of these compounds. Recently, biofield treatment is reported to alter the physical, and structural properties of various living and non-living substances [11,12]. The relation between mass-energy was described by Einstein through a wellknown equation $\mathrm{E}=\mathrm{mc}^{2}$ [13]. Planck $\mathrm{M}$ gave a hypothesis that energy is a property of matter or substances that neither can be created nor destroyed but can be transmitted to other substances by changing into different forms [14]. According to Maxwell JC, every dynamic process in the human body had an electrical significance [15]. Researchers have experimentally demonstrated the presence of electromagnetic field around the human body using medical technologies such as electromyography, electrocardiography and electroencephalogram [16]. This electromagnetic field of the human body is known as biofield and energy associated with this field is known as biofield energy [17]. $\mathrm{Mr}$. Trivedi has the ability to harness the energy from environment or

*Corresponding author: Snehasis Jana, Trivedi Science Research Laboratory Pvt. Ltd., Hall-A, Chinar Mega Mall, Chinar Fortune City, Hoshangabad Rd. Bhopal-462026, Madhya Pradesh, India, Tel: +91-755-666-0006; E-mail: publication@trivedisrl.com

Received July 31, 2015; Accepted August 18, 2015; Published August 18, 2015

Citation: Trivedi MK, Branton A, Trivedi D, Nayak G, Bairwa K, et al. (2015) Fourier Transform Infrared and Ultraviolet-Visible Spectroscopic Characterization f Ammonium Acetate and Ammonium Chloride: An Impact of Biofield Treatment. Mod Chem appl 3: 163. doi:10.4172/2329-6798.1000163

Copyright: ( 2015 Trivedi MK, et al. This is an open-access article distributed under the terms of the Creative Commons Attribution License, which permits unrestricted use, distribution, and reproduction in any medium, provided the original author and source are credited. 
Citation: Trivedi MK, Branton A, Trivedi D, Nayak G, Bairwa K, et al. (2015) Fourier Transform Infrared and Ultraviolet-Visible Spectroscopic Characterization of Ammonium Acetate and Ammonium Chloride: An Impact of Biofield Treatment. Mod Chem appl 3: 163. doi:10.4172/23296798.1000163

Page 2 of 6

universe and can transmit into any object (living or nonliving) around this Globe. The object(s) always receive the energy and responding into useful way, this process is known as biofield treatment [11,12]. Mr. Trivedi's unique biofield treatment is also called as The Trivedi Effect ${ }^{\circ}$, and known to alter the characteristics of many things in the verities of research fields including microbiology [11,18], agriculture $[19,20]$, and biotechnology [21,22]. Recently, impact of biofield treatment on atomic, crystalline and powder characteristics as well as spectroscopic characters of different materials were studied and alteration in physical, thermal and chemical properties were reported $[12,23,24]$

Considering the effects of biofield treatment on various living and nonliving things, the study was aimed to evaluate the impact of biofield treatment on spectral properties of ammonium acetate and ammonium chloride. The effects were analyzed using Fourier Transform Infrared (FT-IR) and Ultraviolet-Visible (UV-Vis) spectroscopic techniques.

\section{Materials and Methods}

\section{Study design}

The ammonium acetate and ammonium chloride were procured from Sigma-Aldrich, India. Each compound was divided into two parts and coded as control and treatment. The control samples were remained as untreated, and treatment samples were handed over in sealed pack to Mr. Trivedi for biofield treatment under laboratory conditions. Mr. Trivedi provided this treatment through his energy transmission process to the treatment groups without touching the samples. The control and treated samples of ammonium acetate and ammonium chloride were evaluated using FT-IR and UV-Vis spectroscopic techniques.

\section{FT-IR spectroscopic characterization}

For FT-IR analysis of control and treated samples of ammonium acetate and ammonium chloride, the samples were crushed into fine powder. Consequently, the crushed powder was mixed in spectroscopic grade $\mathrm{KBr}$ in an agate mortar and pressed into pellets with a hydraulic press. FT-IR spectra of were acquired on Shimadzu's Fourier transform infrared spectrometer (Japan) with frequency range of 500-4000 $\mathrm{cm}^{-1}$ and a maximum resolution of $0.5 \mathrm{~cm}^{-1}$. The analysis were carried out to evaluate the impact of biofield treatment at atomic level such as force constant, dipole moment, and bond strength in chemical structure [25].

\section{UV-Vis spectroscopic analysis}

UV spectra of control and treated ammonium acetate and ammonium chloride were acquired on Shimadzu UV-2400 PC series spectrophotometer with $1 \mathrm{~cm}$ quartz cell and a slit width of $2.0 \mathrm{~nm}$. The study was carried out using wavelength in the range of 200-400 $\mathrm{nm}$. The UV spectral analysis was performed to determine the effect of biofield treatment on the energy gap between bonding $\left(\pi-\pi^{*}\right)$ and nonbonding $\left(n-\pi^{*}\right)$ electrons transition [25].

\section{Results and Discussion}

\section{FT-IR spectroscopic analysis}

The FT-IR spectra of control and treated ammonium acetate are shown in Figure 1 and the IR spectral interpretation results are reported in Table 1. The FT-IR spectrum of control ammonium acetate (Figure 1a) showed the IR peaks at $3024-3586 \mathrm{~cm}^{-1}$ for N-H stretching of $\mathrm{NH}_{4}$ group. These peaks were shifted to higher frequency region i.e., at 3033$3606 \mathrm{~cm}^{-1}$ in treated sample (Figure $1 \mathrm{~b}$ ), which indicated an enhanced force constant of N-H bond as compared to control. IR frequency $(v)$ of stretching vibrational peak depends on two factors i.e., force constant $(\mathrm{k})$ and reduced mass $(\mu)$ which can be explained by following equation [26].

$$
v=1 / 2 \pi c \sqrt{ }(k / \mu) \text {, Here, } \mathrm{c} \text { is speed of light. }
$$

If $\mu$ is constant, then the frequency is directly proportional to the force constant; hence, alteration (increase or decrease) in frequency of any bond indicates a respective change in force constant [25].

The C-H stretching's were appeared at $2826-2893 \mathrm{~cm}^{-1}$ in control sample that were shifted to lower wavenumber in treated sample i.e., at $2817-2881 \mathrm{~cm}^{-1}$. The $\mathrm{C}=\mathrm{O}$ asymmetrical stretchings were appeared at $1660-1702 \mathrm{~cm}^{-1}$ in control sample, which were shifted to higher wavenumber in treated sample i.e., at $1680-1714 \mathrm{~cm}^{-1}$. This could be due to increased bond strength of $\mathrm{C}=\mathrm{O}$ bond in treated sample as compared to control. N-H bending was assigned to peaks at 1533$1563 \mathrm{~cm}^{-1}$ in control sample of ammonium acetate that were observed at $1506-1556 \mathrm{~cm}^{-1}$ in treated sample. It depicted a reduced torsion force of N-H bending after biofield treatment as compared to control. The $\mathrm{C}=\mathrm{O}$ symmetrical stretching was assigned to peak at $1404 \mathrm{~cm}^{-1}$ in control sample, which was observed at higher wavenumber i.e., at $1422 \mathrm{~cm}^{-1}$ in treated sample as compared to control. This shifting of $\mathrm{C}=\mathrm{O}$ bond to higher frequency region was occurred possibly due to increased force constant of $\mathrm{C}=\mathrm{O}$ bond. The $\mathrm{C}-\mathrm{H}$ deformation bends were assigned to the peaks at $1281-1342 \mathrm{~cm}^{-1}$ in control and 1292 $1340 \mathrm{~cm}^{-1}$ in treated sample of ammonium acetate. Likewise, the C-O stretching peaks were observed at $1016-1050 \mathrm{~cm}^{-1}$ in control sample, which were slightly shifted to lower frequency i.e., at 1006-1043 $\mathrm{cm}^{-1}$ in treated sample. This could be due to reduced force constant of C-O bond after biofield treatment as compared to control. Overall, the FTIR results of ammonium acetate suggest a significant impact of biofield treatment at the atomic level i.e., at dipole moment and force constant of respective bonds. The FT-IR data of control ammonium acetate was well supported by the literature [27].

The FT-IR spectra of control and treated ammonium chloride are shown in Figure 2 and the IR spectral interpretation results are reported in Table 2. Krishnan RS reported that $\mathrm{NH}_{4}$ ion has tetrahedral symmetry therefore it showed four distinct mode of oscillations i.e., $v_{1}$ and $v_{2}$ due to single and double degenerate, and $v_{3}$ and $v_{4}$ are triply degenerate $\mathrm{N}-\mathrm{H}$ vibrations, respectively $[28,29]$. The $v_{1}$ and $v_{3}$ peaks were observed at $3010 \mathrm{~cm}^{-1}$ and $3156 \mathrm{~cm}^{-1}$, respectively in control (Figure 2a). Whereas, these were observed at $3029 \mathrm{~cm}^{-1}\left(v_{1}\right)$ and 3124 $\mathrm{cm}^{-1}\left(v_{3}\right)$ in treated sample (Figure $2 \mathrm{~b}$ ). The result showed an upstream shifting of peak $v_{1}$ and downstream shifting of peak $v_{3}$ in threated sample with respect of control. This could be due to biofield induced alteration in force constant of N-H stretching in treated sample as compared to control. Likewise, the vibrational peaks $v_{2}$ and $v_{4}$ were appeared at $1724 \mathrm{~cm}^{-1}$ and $1402 \mathrm{~cm}^{-1}$, respectively in control sample and $1441 \mathrm{~cm}^{-1}$ $\left(v_{2}\right)$ and $1401 \mathrm{~cm}^{-1}\left(v_{4}\right)$ in treated sample of ammonium chloride. The result showed an upstream shifting of peak $v_{2}$ i.e., from $1724 \mathrm{~cm}^{-1}$ to $1741 \mathrm{~cm}^{-1}$ in treated sample, which depicted a corresponding increase in torsional force of $v_{2}$ oscillation. Additionally, the $\mathrm{N}-\mathrm{Cl}$ stretching was assigned to peak at $710 \mathrm{~cm}^{-1}$ in control sample that was shifted to lower frequency at $665 \mathrm{~cm}^{-1}$ in treated sample. This similarly suggests a possible decrease in force constant of $\mathrm{N}-\mathrm{Cl}$ stretching after biofield treatment as compared to control. Overall, the FT-IR spectral data of control and treated ammonium chloride showed an impact of biofield treatment on the internal oscillation of $\mathrm{NH}_{4}$ group and $\mathrm{N}-\mathrm{Cl}$ stretching. This could be due to alteration in force constant and dipole moment of ammonium chloride molecules after biofield treatment as compared to control. Because of alteration in force constant and bond strength, the 
Citation: Trivedi MK, Branton A, Trivedi D, Nayak G, Bairwa K, et al. (2015) Fourier Transform Infrared and Ultraviolet-Visible Spectroscopic Characterization of Ammonium Acetate and Ammonium Chloride: An Impact of Biofield Treatment. Mod Chem appl 3: 163. doi:10.4172/23296798.1000163
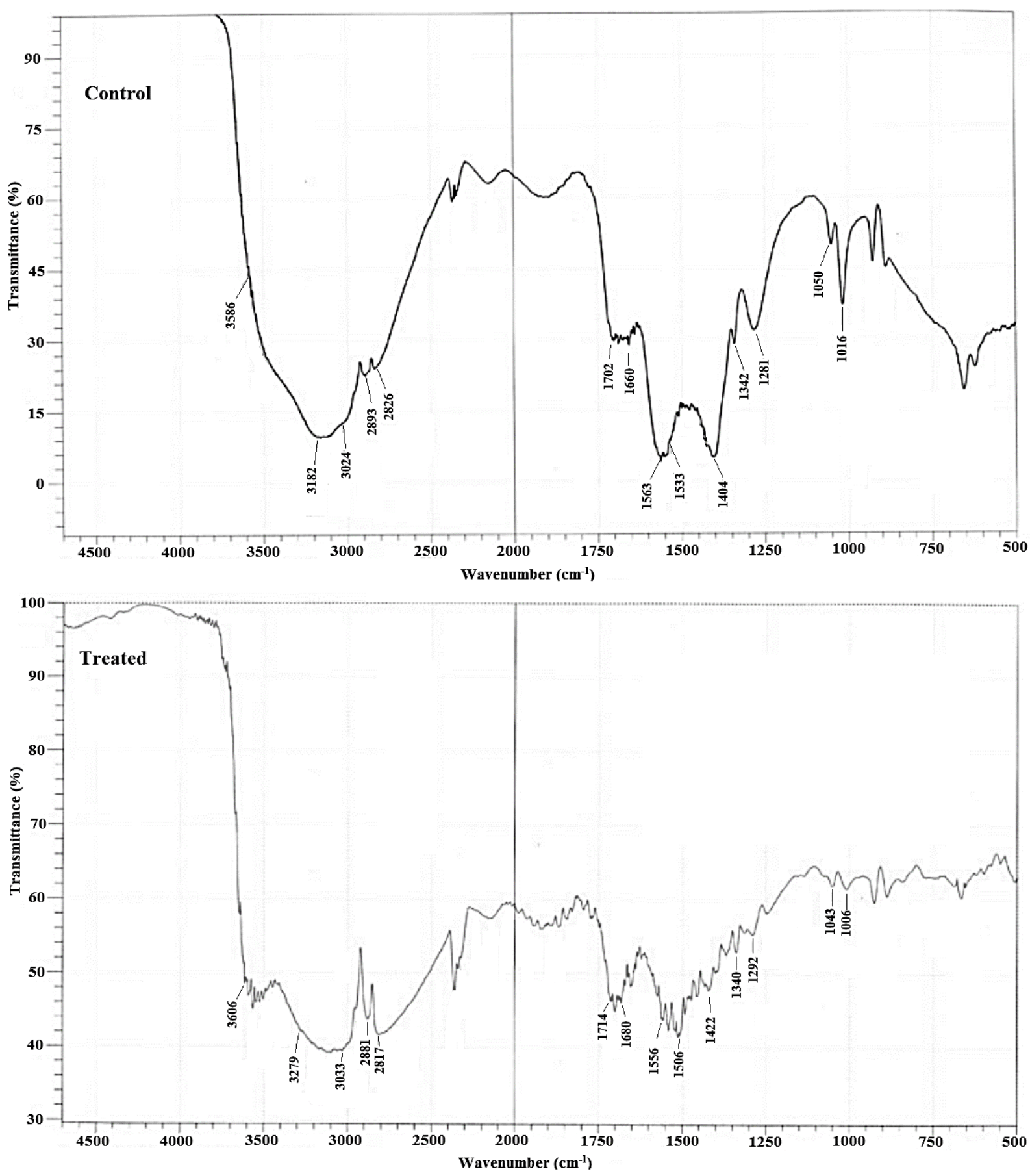

Figure 1: FT-IR spectra of control and treated ammonium acetate.

chemical stability of treated compounds might also be alter. Based on this, it is speculated that biofield treatment could be used to increase the chemical stability of any compound, which might be more useful than the untreated compound.

\section{UV-Vis spectroscopy}

UV spectra of control and biofield treated ammonium acetate are shown in Figure 3. The UV spectrum of control ammonium acetate (Figure 3a) showed the absorption maxima $\left(\lambda_{\max }\right)$ at $258.0 \mathrm{~nm}$. Whereas, in biofield treated sample of ammonium acetate, this absorption maxima $\left(\lambda_{\max }\right)$ was appeared at $221.4 \mathrm{~nm}$ and $204.6 \mathrm{~nm}$ (Figure $3 \mathrm{~b}$ ). As per existing literature on principle of UV spectrophotometer, the compound can absorbs UV light due to the presence of conjugated pi ( $\pi$ ) bonding systems ( $\pi-\pi^{*}$ transition) and nonbonding electron system (n- $\pi^{*}$ transition). There are certain energy gape between $\pi-\pi^{*}$ and $n-\pi^{*}$ orbitals. When this energy gap altered, the wavelength $\left(\lambda_{\max }\right)$ was also altered respectively [25]. Based on this, it is speculated that, due to influence of biofield treatment, the energy gap between $\sigma-\sigma^{*}, \pi-\pi^{*}$ or $n-\pi^{*}$ transition in ammonium acetate molecules might be altered, 
Citation: Trivedi MK, Branton A, Trivedi D, Nayak G, Bairwa K, et al. (2015) Fourier Transform Infrared and Ultraviolet-Visible Spectroscopic Characterization of Ammonium Acetate and Ammonium Chloride: An Impact of Biofield Treatment. Mod Chem appl 3: 163. doi:10.4172/23296798.1000163
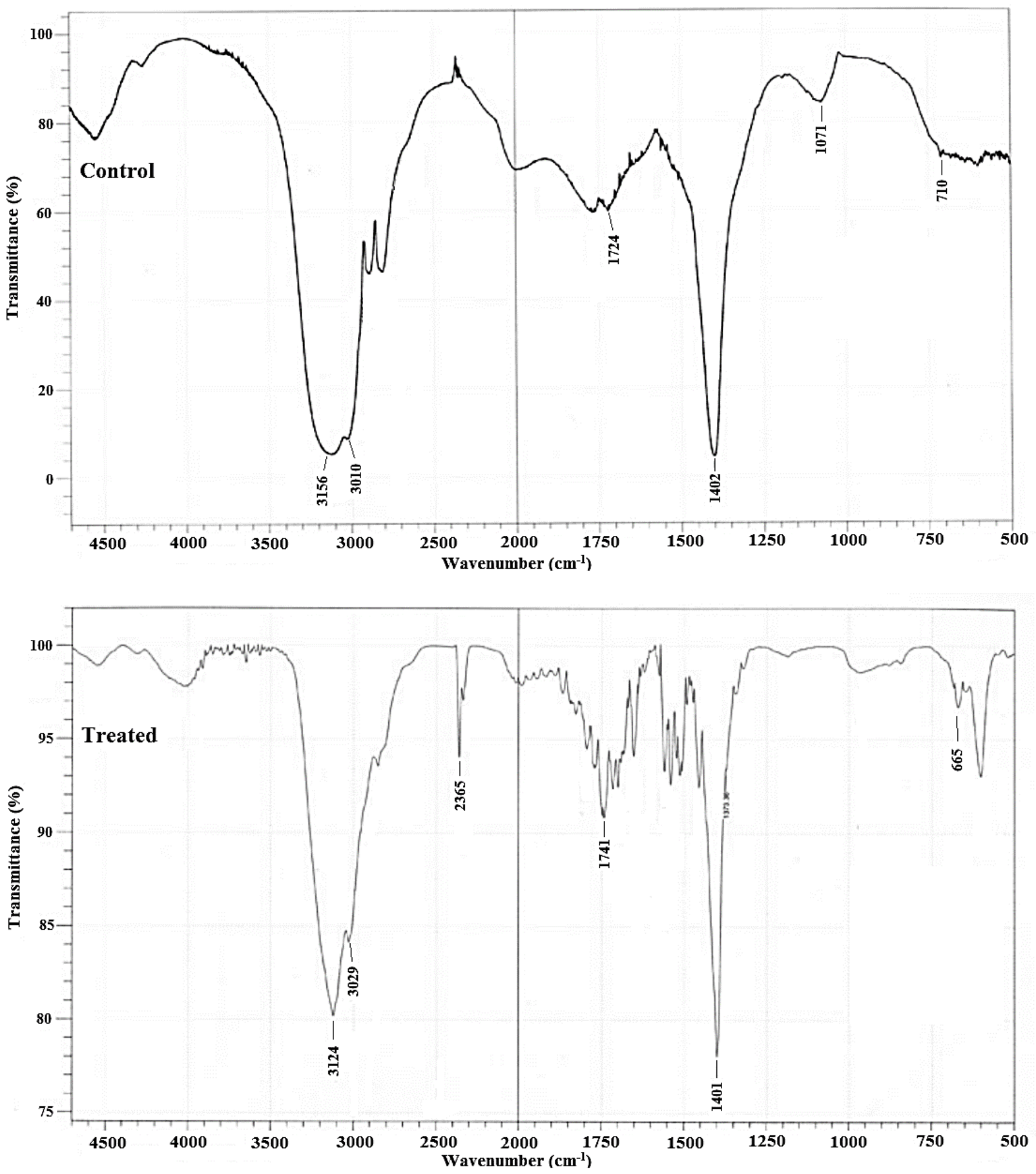

Figure 2: FT-IR spectra of control and treated ammonium chloride.

which causes the shifting of wavelength $\left(\lambda_{\text {max }}\right)$ in treated sample with respect to control.

The UV spectra of control and treated ammonium chloride are shown in Figure 4. The control sample (Figure 4a) exhibited the absorbance maxima $\left(\lambda_{\max }\right)$ at $234.6 \mathrm{~nm}$ and $292.6 \mathrm{~nm}$. Whereas, the biofield treated ammonium chloride exhibited the absorbance maxima $\left(\lambda_{\max }\right)$ at 224.1 and $302.8 \mathrm{~nm}$ (Figure $4 \mathrm{~b}$ ). This slight shifting of $\lambda_{\max }$ after biofield treatment also suggest a possible alteration in energy gap between $\sigma-\sigma^{*}, \pi-\pi^{*}$ or $n-\pi^{*}$ transition in ammonium chloride molecule with respect to control. Altogether, the UV spectral data of both the ammonium acetate and ammonium chloride (control and treated) revealed a considerable impact of biofield treatment on the atomic level of respective compound.

\section{Conclusion}

FT-IR spectrum of biofield treated ammonium acetate showed the alteration in wavenumber of IR peaks assigned to $\mathrm{N}-\mathrm{H}, \mathrm{C}-\mathrm{H}, \mathrm{C}=\mathrm{O}$ and $\mathrm{C}-\mathrm{O}$ stretching as compared to control. Likewise, the biofield treated 
Citation: Trivedi MK, Branton A, Trivedi D, Nayak G, Bairwa K, et al. (2015) Fourier Transform Infrared and Ultraviolet-Visible Spectroscopic Characterization of Ammonium Acetate and Ammonium Chloride: An Impact of Biofield Treatment. Mod Chem appl 3: 163. doi:10.4172/23296798.1000163

Page 5 of 6

\begin{tabular}{|c|c|c|}
\hline \multicolumn{2}{|c|}{ Wave number $\left.\mathbf{( c m}^{-1}\right)$} & \multirow{2}{*}{ Frequency Assigned to group } \\
\hline Control & Treated & $\mathrm{N}-\mathrm{H}$ stretching \\
\hline $3586-3024$ & $3606-3033$ & $\mathrm{C}-\mathrm{H}$ stretching \\
\hline $2893-2826$ & $2881-2817$ & $\mathrm{C}=\mathrm{O}$ asymmetrical stretching \\
\hline $1702-1660$ & $1714-1680$ & $\mathrm{~N}-\mathrm{H}$ bending \\
\hline $1563-1533$ & $1556-1506$ & $\mathrm{C}=\mathrm{O}$ symmetrical stretching \\
\hline 1404 & 1422 & $\mathrm{C}-\mathrm{H}$ deformation \\
\hline $1342-1281$ & $1340-1292$ & $\mathrm{C}-\mathrm{O}$ stretching (ester) \\
\hline $1050-1016$ & $1043-1006$ & \\
\hline
\end{tabular}

Table 1: FT-IR vibrational peaks observed in ammonium acetate.

\begin{tabular}{|c|c|c|}
\hline \multicolumn{2}{|c|}{ Wave number $\left(\mathbf{c m}^{-1}\right)$} & \multirow{2}{*}{ Frequency Assigned to group } \\
\hline Control & Treated & \\
\hline 3156 & 3124 & $v_{3}$ single degenerate N-H oscillation \\
\hline 3010 & 3029 & $v_{1}$ doubly degenerate N-H oscillation \\
\hline 1724 & 1741 & $v_{2}$ Triply degenerate N-H oscillation \\
\hline 1402 & 1401 & $v_{4}$ Triply degenerate N-H oscillation \\
\hline 710 & 665 & $\mathrm{~N}-\mathrm{Cl}$ stretching \\
\hline
\end{tabular}

Table 2: FT-IR vibrational peaks observed in ammonium chloride.
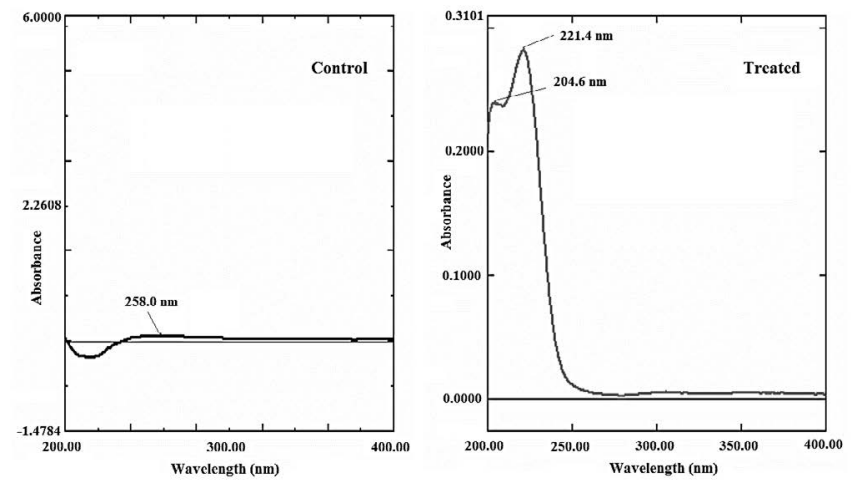

Figure 3: UV spectra of control and treated ammonium acetate.
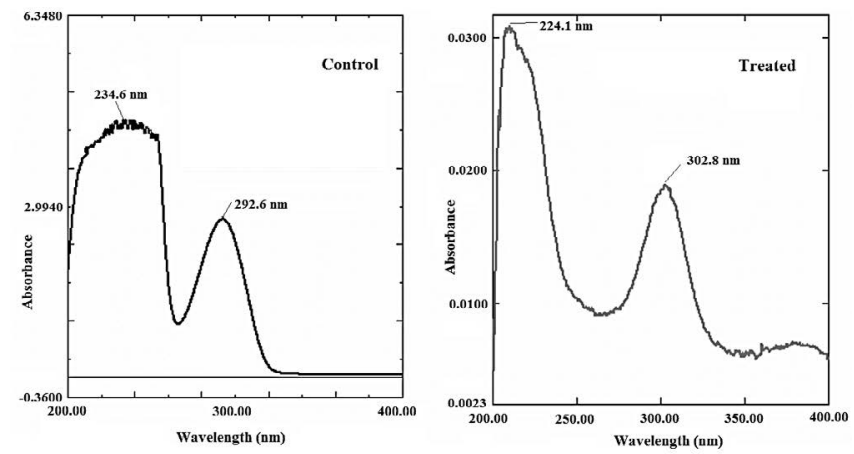

Figure 4: UV spectra of control and treated ammonium chloride.

ammonium chloride showed the alteration in wavenumber of IR peaks assigned to three $\left(v_{1}, v_{2}\right.$, and $\left.v_{3}\right)$ out of four distinct internal oscillations of $\mathrm{NH}_{4}$ group as well as $\mathrm{N}-\mathrm{Cl}$ stretching with respect of control. UV spectra of ammonium acetate and ammonium chloride showed the alteration in absorption maxima $\left(\lambda_{\max }\right)$ after biofield treatment as compared to respective control.

Altogether, the FT-IR results suggest an impact of biofield treatment on atomic level like dipole moment, force constant, bond strength, and flexibility of treated compounds with respect to control. Likely, the UV result suggests the impact of biofield treatment on bonding and nonbonding electron transition of treated compounds with respect to control.

\section{Acknowledgement}

The authors would like thank Trivedi Science"', Trivedi Master Wellness" and Trivedi Testimonials for their consistent support during the work. Authors also like to acknowledge the whole team of MGV Pharmacy College, Nashik for providing the instrumental facility.

\section{References}

1. Budavari S (1989) The Merck Index: An encyclopedia of chemicals, drugs and biologicals. Merck and Co. Inc., Rahway, NJ, USA.

2. Ding L, Tan W, Zhang Y, Shen J, Zhang Z (2008) Sensitive HPLC-ESI-MS method for the determination of tiotropium in human plasma. J Chromatogr Sci 46: $445-449$.

3. Rossoff IS (1974) Handbook of Veterinary Drugs: A Compendium for Research and Clinical Use. Springer Publishing Company, New York, USA.

4. Thellend A, Battioni P, Mansuy D (1994) Ammonium acetate as a very simple and efficient cocatalyst for manganese porphyrin-catalysed oxygenation of hydrocarbons by hydrogen peroxide. J Chem Soc Chem Commun 1994: 1035 1036.

5. Bothara KG (2007) Inorganic Pharmaceutical Chemistry. ( $9^{\text {th }}$ edn) Nirali prakashan, Pragati Books Pvt. Ltd. Pune, India.

6. Mathew JT, Bio LL (2012) Injectable ammonium chloride used enterally for the treatment of persistent metabolic alkalosis in three pediatric patients. J Pediatr Pharmacol Ther 17: 98-103.

7. Oetzel GR, Olson JD, Curtis CR, Fettman MJ (1988) Ammonium chloride and ammonium sulfate for prevention of parturient paresis in dairy cows. J Dairy Sci 71: 3302-3309

8. Costa E, Teixidó N, Usall J, Atarés E, Viñas I (2002) The effect of nitrogen and carbon sources on growth of the biocontrol agent Pantoea agglomerans strain CPA-2. Lett Appl Microbiol 35: 117-120.

9. Chesworth W (2008) Encyclopedia of soil science. Springer science \& Business Media, New York, USA.

10. Blessy M, Patel RD, Prajapati PN, Agrawal YK (2014) Development of forced degradation and stability indicating studies of drugs-A review. J Pharm Anal 4: 159-165.

11. Trivedi MK, Patil S, Shettigar H, Bairwa K, Jana S (2015) Phenotypic and biotypic characterization of Klebsiella oxytoca: An impact of biofield treatment. J Microb Biocshem Technol 7: 203-206.

12. Trivedi MK, Patil S, Tallapragada RMR (2015) Effect of biofield treatment on the physical and thermal characteristics of aluminium powders. Ind Eng Manage 4: 151.

13. Einstein A (1905) Does the inertia of a body depend upon its energy-content? Ann Phys 18: 639-641.

14. Planck $M$ (1903) Treatise on thermodynamics. ( $3^{\text {rd }}$ edn) English translated by Alexander OGG, Longmans, Green, London (UK).

15. Maxwell JC (1865) A dynamical theory of the electromagnetic field. Phil Trans R Soc Lond 155: 459-512.

16. Rivera-Ruiz M, Cajavilca C, Varon J (2008) Einthoven's string galvanometer: the first electrocardiograph. Tex Heart Inst J 35: 174-178.

17. Rubik B (2002) The biofield hypothesis: its biophysical basis and role in medicine. J Altern Complement Med 8: 703-717.

18. Trivedi MK, Patil S, Shettigar H, Gangwar M, Jana S (2015) Antimicrobia sensitivity pattern of Pseudomonas fluorescens after biofield treatment. J Infect Dis Ther 3: 222.

19. Sances F, Flora E, Patil S, Spence A, Shinde V (2013) Impact of biofield treatment on ginseng and organic blueberry yield. Agrivita J Agric Sci 35.

20. Lenssen AW (2013) Biofield and fungicide seed treatment influences on soybean productivity, seed quality and weed community. Agricultural Journa 8: 138-143. 
Citation: Trivedi MK, Branton A, Trivedi D, Nayak G, Bairwa K, et al. (2015) Fourier Transform Infrared and Ultraviolet-Visible Spectroscopic Characterization of Ammonium Acetate and Ammonium Chloride: An Impact of Biofield Treatment. Mod Chem appl 3: 163. doi:10.4172/23296798.1000163

21. Patil SA, Nayak GB, Barve SS, Tembe RP, Khan RR (2012) Impact of biofield treatment on growth and anatomical characteristics of Pogostemon cablin (Benth.). Biotechnology 11: 154-162.

22. Altekar N, Nayak G (2015) Effect of biofield treatment on plant growth and adaptation. J Environ Health Sci 1: 1-9.

23. Trivedi MK, Tallapragada RR (2008) A transcendental to changing metal powder characteristics. Met Powder Rep 63: 22-28.

24. Dabhade VV, Tallapragada RR, Trivedi MK (2009) Effect of external energy on atomic, crystalline and powder characteristics of antimony and bismuth powders. Bull Mater Sci 32: 471-479.

25. Pavia DL (2001) Introduction to Spectroscopy. (3 $3^{\text {rd }}$ edn) Thomson Learning, Singapore.
26. Stuart $\mathrm{BH}$ (2004) Infrared spectroscopy: Fundamentals and applications analytical techniques in the sciences (AnTs). John Wiley \& Sons Ltd., Chichester, UK.

27. Alias SS, Chee SM, Mohamad AA (2014) Chitosan-ammonium acetateethylene carbonate membrane for proton batteries. Arab J Chem http://dx.doi org/10.1016/j.arabjc.2014.05.001.

28. Krishnan RS (1947) Raman spectrum of ammonium chloride and its variation with temperature. Proc Ind Acad Sci A 26: 432-449.

29. Max JJ, Chapados C (2013) Aqueous ammonia and ammonium chloride hydrates: Principal infrared spectra. J Mol Struct 1046: 124-135. 